\title{
Synonymy and chemotaxonomy of Australian Pertusaria species (Lichenes) based on Australian type specimens
}

\author{
Alan W. Archer
}

\begin{abstract}
Archer, Alan W. (National Herbarium of New South Wales, Royal Botanic Gardens, Sydney, NSW, Australia 2000) 1991. Synonymy and chemotaxonomy of Australian Pertusaria species (Lichenes) based on Australian type specimens. Telopea 4(2): 165-184. The type specimens of 44 Australian taxa and several non-Australian taxa in the genus Pertusaria were examined; 17 of these names are synonyms for previously described taxa. P. melaleuca var. trispora Müll. Arg. is a synonym of P. pustulata var. trimera Müll. Arg., which is raised to species level as P. trimera (Müll. Arg.) A. Archer, comb. nov. The remaining 28 names are accepted as legitimate. Lectotypes are selected for P. communis var. neo-caledonica Nyl., P. confluens Müll. Arg., P. irregularis Müll. Arg., P. meridionalis var. xanthostoma Müll. Arg., P. microsporella Zahlbr. and P. rhodotropa Müll. Arg. The chemistry of the specimens examined is reported.
\end{abstract}

\section{Introduction}

Between 1882 and 1895 J. Müller (Müll. Arg.) described 39 new taxa in the genus Pertusaria, based on specimens collected in Australia (J. Müller 1882a, 1883, 1884, 1891a, 1893a, 1893b, 1895a, 1895b). Additional taxa in the genus were described by G. Körber (1862) and C. Knight (1882, Shirley 1889) giving a total of 44 taxa based on Australian type material. The type specimens of these taxa have received little study apart from nomenclatural changes by Zahlbruckner (1928) to remove synonyms, and listing for the Index to Type Specimens of Australian Lichens (Filson 1986). This note reports the results of a chemotaxonomic examination of the type specimens of the 44 Australian taxa and relevant non-Australian taxa, and more recent collections of the same taxa. An index of all taxa mentioned is included. No key is included in this account as several new species have been found; these, together with a key to the genus in Australia, will be published at a later date.

\section{Material and methods}

The material examined consisted of type specimens from BRI, G, W, WELT and WRSL, and additional specimens from AD, ANUC, BRIU, CBG, GZU, H, HO, MEL, NSW and PERTH and from the herbaria of J.A. Elix, W.H. Ewers, J. Hafellner, K. Kalb, G. Kantvilas, H.T. Lumbsch, H. Mayrhofer, R.W. Rogers, G.N. Stevens, H. Streimann and D. Verdon. All types cited here have been examined unless otherwise indicated.

Slices of verrucae were mounted in water for measurement of spore size; the spore descriptions follow the nomenclature of Dibben (1980: 10).

Thin-layer chromatography was carried out on acetone extracts using the mobile phases A and C of Culberson (1972) and the compounds were detected with UV light, sulphuric acid (Culberson 1972) and MBTH (Archer 1978). Perlatolic acid and 
its derivatives were separated using an alkaline mobile phase (Archer 1987) and differentiated with MBTH. The unidentified compound UN1 (Dibben 1980: 13), which was found in some Australian specimens, corresponds to the unidentified depside $\mathrm{mH}$ examined by Hanko (Hanko 1983: 50).

\section{Results}

1. Pertusaria aberrans Müll. Arg.

(Müller 1893a: 42).

TYPE: Victoria: Loughton Gully, Lakes Entrance, F.R.M. Wilson 1517, Mar 1889; holo G; iso NSW.

Thallus off-white to pale greyish white, coarsely areolate and cracked, surface smooth and slightly shiny, corticolous; verrucae numerous, contiguous, almost completely covering the thallus surface, c. $1 \mathrm{~mm}$ wide, immersed, occasionally slightly raised above the surface, centre slightly depressed; ostioles 1 per verruca, black, conspicuous, $0.1-0.5 \mathrm{~mm}$ diam., becoming slightly sunken and disc-like; spores $2-4$ per ascus, uniseriate, ellipsoid, smooth, 75-87 $\mu \mathrm{m}$ long, 28-36 $\mu \mathrm{m}$ wide.

Chemistry: stictic acid.

$P$. aberrans somewhat resembles $P$. trypetheliiformis (Nyl.) Nyl. (Nylander 1859) [Type: Tahiti, Lepine 17; holo H-NYL 23588] but is distinguished from that species by the smooth spores, whereas they are rough in $P$. trypetheliiformis. $P$. aberrans is known only from the type specimen.

2. Pertusaria concava Müll. Arg.

(Müller 1895a: 640)

TYPE: VICTORIA: The Grampians, Sullivan s.n., 1894 ; holo G.

Thallus off-white to pale greyish white, cracked and areolate, surface smooth and dull, saxicolous; apothecia disciform, abundant, conspicuous, $0.3-0.7 \mathrm{~mm}$ diam., the margins concolorous with the thallus, discs black, 0.1-0.4 mm diam.; spores 6-8 per ascus, uniseriate, ellipsoid, smooth, 30-45 $\mu \mathrm{m}$ long, $17-25 \mu \mathrm{m}$ wide.

Chemistry: $\mathrm{K}+$ red, KC-, C-, Pd + yellow; norstictic acid.

$P$. concava resembles two saxicolous Pertusaria species from New Zealand, $P$. erumpescens Nyl. and $P$. perfida Nyl. The three taxa have 8-spored asci with similar spores and contain norstictic acid but $P$. erumpescens has verrucae with ostioles and $P$. perfida has $1-3$ discs per verruca in contrast to the single disc in $P$. concava. Both New Zealand taxa are reported to be endemic (Galloway 1985).

$P$. concava is distinguished from the morphologically similar Australian P. paratropa Müll. Arg. (q.v.) by the presence of norstictic acid.

Also eXamined: New South Wales : Jenolan Caves, Wilson s.n., Sep 1897 (NSW L4581); Tinderry Mtns, 11 km ESE of Michelago, Verdon 2070, Jan 1976 (CBG 8403934). VICTORIA: Lookout Hill, $1.5 \mathrm{~km}$ E of Myrtleford, Streimann 35931, Dec 1985 (CBG 9003890 p.p., H); Trentham Falls, c. 20 km E of Daylesford, Hafellner 15752a, July 1986 (GZU).

3. Pertusaria confluens Müll. Arg.

(Müller 1895a: 638).

LECTOTYPE (here selected): QuEENSLAND: Toowoomba, Hartmann s.n., 1894; lecto G; residual syntype: $G$. 
Thallus dull yellow, thin, somewhat wrinkled and folded, surface smooth and dull, corticolous; verrucae numerous, scattered, somewhat elongated hemispherical, occasionally confluent, not constricted at the base, $0.5-1 \mathrm{~mm}$ wide; ostioles inconspicuous, dark, 1-3 per verruca; spores $4-8$ per ascus, irregularly uniseriate, ellipsoid to slightly fusiform, smooth, $48-55 \mu \mathrm{m}$ long, 23-28 $\mu \mathrm{m}$ wide.

CHEMISTRY: K+ weak yellow, KC-, C-, Pd-; thiophaninic and stictic acids with traces of constictic and hypoconstictic acids.

When Müller described $P$. confluens he cited two specimens from Queensland collected respectively by Hartmann and Knight; the specimen collected by Hartmann is the only specimen with a written reference to the publication 'Lecan. \& Lecid. Aust. n. 26' [Lecanoreae et Lecideeae Australienses novae, species number 26 (Müller 1895a)] and this specimen is therefore chosen as lectotype.

Also eXAMINED: QuEENSLAND: Weyba Creek, c. $70 \mathrm{~km}$ SE of Gympie, on mangrove, Hafellner 17992, July 1986 (GZU).

\section{Pertusaria crassilabra Müll. Arg.}

(Müller 1893b: 126).

TYPE: VICTORIA: Loutit Bay [near Lornel, Luehmann s.n., 1891; holo G.

Thallus thick, off-white, somewhat granular, minutely cracked and areolate, surface smooth and dull, saxicolous; verrucae conspicuous, scattered, immersed or flattened hemispherical, with constricted bases, $0.5-1.5 \mathrm{~mm}$ diam., the centre often depressed; ostioles conspicuous, large, black, 1 per verruca, $0.2-0.5 \mathrm{~mm}$ diam.; spores 8 per ascus, irregularly biseriate, ellipsoid, smooth, 65-72 $\mu \mathrm{m}$ long, 30-32 $\mu \mathrm{m}$ wide.

ChemistRY: K, KC, C, Pd -; orthothelin (2, 4, 5-trichloro-norlichexanthone) and a second minor unidentified compound, blue fluorescence, Rf 14 (C), 10 (A), no colour with sulphuric acid.

$P$. crassilabra is known only from the type specimen.

\section{Pertusaria elliptica Müll. Arg. (Müller 1895a: 635).}

TYPE: QueENSLAND: [Goodna, fide Shirley (1896)], Shirley 1754 p.p., 1893; holo G.

Thallus off-white or pale grey to pale olive green, thin, surface smooth or slightly rough and dull, corticolous; verrucae conspicuous (but less conspicuous on rough substrates), scattered, slightly flattened hemispherical, rounded or elongated or irregular in outline, sometimes becoming constricted at the base and sometimes concave on top, 0.5-1.5 mm wide; ostioles conspicuous, black, 1 or 2 per verruca; spores 3 to 4 per ascus, uniseriate, elongate-ellipsoid to subfusiform, rough, $80-112(-125)$ $\mu \mathrm{m}$ long, 30-42 $\mu \mathrm{m}$ wide.

Chemstry: K-, KC-, C-, Pd-; 4,5-dichlorolichexanthone, 2-O-methylperlatolic acid and 2'-O-methylperlatolic acid.

$P$. elliptica is characterised by the four rough spores per ascus and differentiated from the similar P. leucothelia by the presence of the isomeric O-methylperlatolic acids. It occurs on mangroves and other unspecified trees in eastern Queensland, New South Wales and New Caledonia.

ALso EXAMINED (7 out of 28): QueEnSLAND: Whitsunday Island, Whitehaven Beach, Gilbert, Aug 1974 (HO 50948); Hook Island [E of Proserpine], Gilbert, - (HO 50943); Port Alma, Rogers 708, June 1975 (BRIU); Glasshouse Mtns, S of Tibrogargan Creek, Hafellner 19454, Aug 1986. New 
South Wales: Hastings Point, Cudgera Creek, Stevens 1933, Aug 1975 (BRIU). Australian CAPITAL Territory: Cotter Caves, $20 \mathrm{~km} \mathrm{~W}$ of Canberra, on Casuarina, Elix 9075, June 1981 (ANUC). New Caledonia: Nouméa, Wilson s.n., July 1891 (H).

6. Pertusaria erythrella Müll. Arg.

(Müller 1893a: 41).

TYPE: VICTORIA: Lakes Entrance, F.R.M. Wilson 999, 1891; holo G.

Thallus off-white to pale greyish white, slightly cracked and areolate, surface slightly wrinkled and dull, sorediate, corticolous; soralia white, numerous, conspicuous, disclike or sub-hemispherical, sometimes constricted at the base, $0.5-1 \mathrm{~mm}$ diam., upper surface sometimes becoming smooth and pale reddish brown; asci and spores not seen.

CHEMistry: $\mathrm{K}+$ yellow-orange, $\mathrm{KC}-, \mathrm{C}-, \mathrm{Pd}+$ yellow; norstictic acid with stictic acid (tr), with or without lichexanthone.

Also examined: QueEnsLAND: Gambubal State Forest, Bald Mtn, Hafellner 16340, Sep 1986 (GZU). New South Wales: Dural Extension of Cumberland State Forest, c. $4 \mathrm{~km} \mathrm{~S}$ of Dural, Archer P97, Mar 1990 (NSW); Stanwell Park, Cheel s.n., Aug 1902 (NSW L4526); Fitzroy Falls, $16 \mathrm{~km}$ SE of Moss Vale, Verdon 3030, Aug 1977 (CBG 7802735); Reedy Creek, Marble Arch, $48 \mathrm{~km}$ S of Braidwood, Elix 4428, Mar 1978; Currawon State Forest, 14 km NW of Batemans Bay, Streimann 27689, May 1987 (CBG 830945). TASMANIA: Deal Island, Kents Group, Bass Strait, Whinray s.n., Dec 1970 (MEL 1012473).

P. erythrella resembles corticolous $P$. paeminosa (q.v.) but is distinguished from that species by the presence of norstictic acid.

7. l'ertusaria gibberosa Müll. Arg.

(Müller 1882a: 486).

Type: Tasmania: s. loc., F. Müller s.n., 1882; holo G.

Pertusaria virginea Müll. Arg. (Müller 1882a: 486). Type: New South WALES: Parramatta, Woolls s.n., 1879; holo G.

Pertusaria moffatiana Müll. Arg. (Müller 1883: 79). TYpe: Victoria: Mount Macedon, Moffat s.n., 1882; holo G.

Pertusaria nitidula Müll. Arg. (Müller 1893a: 42). Type: Victoria: s. loc., F.R.M. Wilson 468 p.p., 1891; holo G.

Pertusaria graphidioides Müll. Arg. (Müller 1893a: 42). TYPE: VictorIA: Doncaster, F.R.M. Wilson 492, 1892; holo G.

Pertusaria microsporella Zahlbr. (Zahlbruckner 1928: 180); Pertusaria microspora Müll. Arg. (Müller 1895a: 637); nom. illeg. non P. microspora Krempelh. 1876. LeCtOTYPE (here selected): VICTORIA: Loutit Bay, Luehmann s.n.; lecto G; residual syntype G.

Thallus variable, thick and continuous to thin and discontinuous, off-white or greyish-white to yellowish white, slightly cracked and areolate, surface smooth or slightly wrinkled, dull, corticolous; verrucae conspicuous, numerous to scattered, occasionally confluent, hemispherical or slightly or conspicuously flattened hemispherical with irregular outline, becoming constricted at the base, $0.5-1.5 \mathrm{~mm}$ wide; ostioles pale brown to black, usually conspicuous, sometimes sunken, rarely raised, 1 to 8 per verruca; spores 8 per ascus, uniseriate, ellipsoid, smooth, 32-65(-70) $\mu \mathrm{m}$ long, 15-30 $\mu \mathrm{m}$ wide.

Chemistry: K-, KC-, C-, Pd-; 4,5-dichlorolichexanthone, 2'-O-methylperlatolic acid and anzaic acid (tr). 
P. gibberosa is characterised by the white to grey-white thallus, the negative chemical reactions and, in particular, the usually abundant asci, each containing eight uniseriate spores.

The species is widely distributed across Australia and is common in south-eastern mainland Australia and Tasmania; it grows on Acacia, Banksia, Bedfordia, Casuarina, Ceratopetalum, Cyathodes, Exocarpos, Pomaderris and other unspecified trees, from sealevel to c. $1100 \mathrm{~m}$. It is doubtfully distinguished from the similar P. woollsiana Müll. Arg. (q.v.) only by the different chemistry.

Older herbarium specimens of $P$. gibberosa were often identified as $P$. anarithmetica Müll. Arg. from Costa Rica (Müller 1891b), but examination of one of the two syntypes [Costa Rica, San Jose, Pettier 5262, 1890; G] showed that the spores are biseriate and 2'-O-methyl perlatolic acid is absent. P. anarithmetica was reported to occur in Australia (Müller 1893a) but the specimen on which this report was based ['Doncaster, Wilson n.470' (NSW L4616)] is $P$. gibberosa. P. communis DC. was reported from Victoria (Wilson 1887) but this specimen, from Camperdown (NSW L4434), is also P. gibberosa.

The type specimens of $P$. gibberosa, $P$. virginea and $P$. nitidula are indistinguishable; the type specimen of $P$. moffatiana has slightly flattened verrucae but is otherwise identical with $P$. gibberosa and the type specimen of $P$. graphidioides has somewhat larger ostioles. $P$. 'microspora' was separated as a species by the smaller spores, reported by Müller as 30-35 $\mu \mathrm{m}$ long and 15-19 $\mu \mathrm{m}$ wide but in the lectotype the spores were $40-$ $50 \mu \mathrm{m}$ long and 20-25 $\mu \mathrm{m}$ wide, similar to those of $P$. gibberosa. Müller himself referred to similarities with $P$. gibberosa and $P$. nitidula in the protologue to $P$. 'microspora'. The chemistry of all the type specimens is iaienticai.

In the protologue to $P$. 'microspora' Müller cited specimens from Loutit Bay, Mt Erica, Upper Yarra and Mt Mueller; the specimen from Loutit Bay was chosen and annotated as lectotype by R. Filson in 1971 and this specimen is selected here.

The earliest name for P. gibberosa may be P. pertractata Stirton (Stirton 1876) but the holotype of this taxon, from Tasmania, was not available for study. A recent examination of this material found similarities with $P$. gibberosa but the specimen was too small for a definite conclusion to be reached ( $G$. Kantvilas, in litt.).

Also eXAMINED (8 out of 85): QueEnsLand: Brisbane, Chermside, Rogers 4077, Aug 1977 (BRIU); Bunya Mtns, Mt Mowbullan, Kalb 20404, Aug 1988 (herb. KALB). New SoutH Wales: Jenolan Caves, Wilson s.n., Sep 1897 (NSW L4577). Australian CaPITAL TerRitory: Condor Creek, c. 25 $\mathrm{km}$ W of Canberra, Mayrhofer 5338, Sep 1981 (GZU). VICTORIA: Mt William summit, Archer P76, Oct 1989 (NSW). TASMANIA: Raoul Lookout, Tasman Peninsula, Kantvilas 617/80, Nov 1980 (HO). South Australia: Bangham Scrub, $14 \mathrm{~km} \mathrm{~N}$ of Francis, Munir 5553E, Nov 1981 (AD 20140). Western Australia: Ravensthorpe, Bratt 67/312 (H0 51083).

\section{Pertusaria hartmannii Müll. Arg.}

(Müller 1882a: 485).

Pertusaria trypetheliiformis (Nyl.) Nyl. var. hartmannii (Müll. Arg.) Müll. Arg. (Müller 1884: 351). TYPE: QueENSLAND: Toowoomba, Hartmann s.n.; holo G.

Pertusaria muelleriana Zahlbr. (Zahlbruckner 1928: 181); Pertusaria albinea Müll. Arg. (Müller 1895a: 635); nom. illeg. non Tuckerman 1877. TYPE: QuEENSLAND: [Goodna, fide Shirley (1896)], Shirley 1754 p.p., 1893; holo G.

Thallus thin, pale greyish white to dull greenish white, continuous or slightly cracked, surface smooth to slightly wrinkled, dull, corticolous; verrucae conspicuous, scattered, occasionally confluent, slightly flattened, hemispherical or irregular in outline, 
becoming constricted at the base, $0.5-1.5(-2.5) \mathrm{mm}$ wide; ostioles conspicuous, black, 1 to 8 per verruca; spores 2 per ascus, uniseriate, elongate-ellipsoid, smooth, 120$170(-200) \mu \mathrm{m}$ long, 35-60 $\mu \mathrm{m}$ wide.

Chemistry: $\mathrm{K}+$ red, $\mathrm{KC}-, \mathrm{C}$-, $\mathrm{Pd}+$ yellow; norstictic and perlatolic acids, with or without lichexanthone (tr).

P. hartmannii is found in eastern Queensland where it grows on mangroves and other unspecified trees. Specific status as $P$. hartmanii is appropriate for this taxon as it is chemically and morphologically distinct from $P$. trypetheliiformis.

$P$. hartmannii is chemically and morphologically similar to the two-spored P. subobductans Nyl., described from Japan (Nylander 1890) but an examination of the lectotype of this taxon [Japan, Murayama, E. Almquist s.n., 1879; lecto H. Kashiwadani 1975, H-NYL 23264] showed it to possess larger, flattened verrucae, inconspicuous pale ostioles and smaller spores.

$P$. hartmannii is characterised by the presence of norstictic and perlatolic acids and by having two large, smooth spores per ascus.

Also eXamined: QueEnsland: Tingalpa Creek, Wilson, Aug 1896 (NSW L4640); Weyba Creek, SW of Noosa Heads, Stevens 2373, Dec 1975 (BRIU); Mt Fox, $43 \mathrm{~km}$ SW of Ingham, Elix 20365, June 1986 (ANUC); Noosa River, $70 \mathrm{~km}$ S of Gympie, Hafellner 19212, July 1986 (GZU); Tandora, c. $25 \mathrm{~km}$ ENE of Maryborough, Hafellner 18278, Aug 1986 (GZU).

9. Pertusaria irregularis Müll. Arg.

(Müller 1895a: 638).

LeCTOTYPE (here selected): QueENSLAND: Thursday Island, Knight 31 p.p.; lecto G; residual syntype: Queensland: Thursday Island, Knight 41 p.p.; G.

[non P. irregularis Magn. (Magnusson 1955)]

Thallus pale yellowish white, thick, coarsely cracked and areolate, surface smooth and dull, corticolous; verrucae inconspicuous, flattened hemispherical, not constricted at the base, c. $1 \mathrm{~mm}$ wide; ostioles conspicuous, black, 1 to 3 per verruca; spores 2 per ascus, irregularly uniseriate, fusiform, smooth, (120-)130-155 $\mu \mathrm{m}$ long, 35-47 $\mu \mathrm{m}$ wide.

Chemistry: 4,5-dichlorolichexanthone.

$P$. irregularis is known only from the type specimens.

When J. Müller described $P$. irregularis he cited two specimens from Thursday Island collected by Knight, viz 31 p.p. and 41 p.p.; the specimen labelled ' 31 pr.p.' is the only specimen with a written reference to the publication, 'Lecan. \& Lecid. n. 24' [Lecanoreae et Lecideeae Australienses, species number 24 (Müller 1895a)] and is therefore chosen as lectotype. A third specimen from $\mathrm{G}$, labelled 'Thursday Is. $\mathrm{N}$. Queensland Knight 1887 ' has no collector's number and has 8 spores per ascus; it is not $P$. irregularis.

$P$. irregularis is characterised by the two large, fusiform spores per ascus.

10. Pertusaria leiocarpella Müll. Arg.

(Müller 1895a: 636).

TYPE: QueENSLAND: s.loc., Knight 11, 1887; holo G.

Thallus pale yellowish grey to pale greenish grey, minutely cracked and areolate, surface wrinkled and dull, corticolous; verrucae conspicuous, scattered, $0.4-0.8 \mathrm{~mm}$ 
diam., flattened hemispherical, often irregular in outline, slightly constricted at the base; ostioles inconspicuous, pale, translucent, $0.05-0.4 \mathrm{~mm}$ diam., becoming dark at the centre, 1 per verruca; spores 8 per ascus, irregularly uniseriate to biseriate, ellipsoid, smooth, 55-80 $\mu \mathrm{m}$ long, 25-35 $\mu \mathrm{m}$ wide.

CHEMISTRY: 4,5-dichlorolichexanthone, stictic acid and constictic acid (tr).

$P$. leiocarpella is characterised by the biseriate spores and translucent ostioles; it occurs in eastern Queensland where it grows on mangroves and other unspecified trees.

Also eXAMINED: QuEENSLAND: Keppel Sands, near Rockhampton, Rogers 895, June 1975 (BRIU); Kuranda Range, near Cairns, Kalb 19810, Aug 1988 (herb. KALB); Sunshine Coast, c. 100 km N of Brisbane, Kalb 19761, 19768, Sep 1988 (herb. KALB).

11. Pertusaria leucostigma Müll. Arg.

(Müller 1884: 462).

TyPe: QueEnsLAND: Cunninghams Gap, Hartmann s.n., 1883; holo G.

Thallus pale olive-green, coarsely cracked and areolate, somewhat wrinkled, surface dull and minutely tuberculate, corticolous; verrucae conspicuous, scattered, rarely confluent, slightly flattened hemispherical, not constricted at the base, 1-1.5 mm diam.; ostioles inconspicuous, pale, becoming dark, 1 per verruca; spores 8 per ascus, irregularly uniseriate, subfusiform to ellipsoid, smooth, 75-105 $\mu \mathrm{m}$ long, 30-45 $\mu \mathrm{m}$ wide.

Chemistry: K-, KC-, C-, Pd-; 2-O-methylperlatolic acid and lichexanthone.

P. leucostigma is characterised by the eight fusiform spores and the presence of 2-Omethylperlatolic acid. It grows on mangroves, eucalypts, Nothofagus and other unspecified trees in Queensland and New South Wales. It is distinguished from P. subrigida (q.v.), which also has 8 fusiform spores per ascus, by the presence of 2-Omethylperlatolic acid.

Also eXamined: Queensland: Natural Arch National Park, Elix 1120, Aug 1975 (ANUC); Brisbane, Deception Bay, Lumbsch 5381i, Aug 1987 (herb. LUMBSCH). New South Wales: Bundeena, Royal National Park, Elix 2601, Apr 1976 (ANUC); Blue Mountains, Glenbrook, Sassafras Gully, Kalb 18872, 18873, 20513, July 1988 (herb. KALB); Batemans Bay, Buckenbowra River, Elix 10985, May 1983, Kalb 18224, 18907, Aug 1988 (herb. KALB); 1 km W of Mt Banda Banda, Kantvilas 500/88, Aug 1988 (HO); Myall River State Forest, 15 km E of Stroud River, Archer P112, Apr 1990 (NSW).

\section{Pertusaria leucostomoides Zahlbr.} (Zahlbruckner 1928: 172).

Pertusaria leucostoma Müll. Arg. (Müller 1895a: 636) nom. illeg. non P. leucostoma (Bernh.) Mass. TYPE: QueENSLAND: Toowoomba, Hartmann s.n., 1894; holo G.

Thallus off-white to pale olive-green, slightly cracked, surface smooth and dull, corticolous; verrucae conspicuous, scattered, slightly flattened hemispherical to subconical, rarely confluent, not constricted at the base, $0.4-0.8 \mathrm{~mm}$ diam.; ostioles conspicuous, white, 1 or rarely 2 per verruca; spores $4-8$ per ascus, uniseriate, ellipsoid, smooth, 65-70 $\mu \mathrm{m}$ long, 25-32 $\mu \mathrm{m}$ wide.

CHEMISTRY: 4,5-dichlorolichexanthone, stictic and norstictic (tr) acids.

$P$. leucostomoides is morphologically and chemically similar to P. leiocarpella (q.v.) and is differentiated from that species by the arrangement of the spores in the ascus, and 
the white ostioles, unique in Australian Pertusaria. The verrucae are conspicuous and Müller (loc. cit.) compared them to Egyptian pyramids. P. leucostomoides is known only from the type specimen.

13. Pertusaria leucothelia Müll. Arg.

(Müller 1895a: 637).

TYPE: VICTORIA: s. loc., Knight 147, 1887; holo G.

Thallus dull greyish black, surface dull, corticolous; verrucae few, scattered, inconspicuous, $0.5-1 \mathrm{~mm}$ wide, iregularly hemispherical; ostioles inconspicuous, black, 1 or 2 per verruca; spores 4 per ascus, uniseriate, ellipsoid, rough, 87-97 $\mu \mathrm{m}$ long, 35$42 \mu \mathrm{m}$ wide.

CHEMISTRY: 4,5-dichlorolichexanthone and planaic acid.

The type specimen of $P$. leucothelia is too small for examination by thin-layer chromatography and is overgrown by two other crustose species; the chemistry reported above is based on that of the two additional specimens examined which are tentatively identified as $P$. leucothelia.

$P$. leucothelia is morphologically similar to $P$. elliptica; both have four rough, ellipsoid spores per ascus but the species are distinguished by the absence of 2'-O- or 2-Omethylperlatolic acids from $P$. leucothelia.

Further specimens are required to confirm the chemistry and status of $P$. leucothelia.

Also EXAMINED: NeW SOUTH WALES: Warrumbungles, Ewers 3667, July 1989 (herb. EWERS). Australian Capital Territory: Cotter Reserve, $20 \mathrm{~km} \mathrm{~W}$ of Canberra, $500 \mathrm{~m}$, on Casuarina, Mayrhofer 5545, Sep 1981 (GZU).

14. Pertusaria leucoxantha Müll. Arg.

(Müller 1895a: 637).

TYPE: QueENSLAND: Thursday Island, Knight 280, 1887; holo G.

Thallus dull pale yellow, thin, slightly cracked, surface smooth and shiny, esorediate, saxicolous; verrucae inconspicuous, scattered, somewhat flattened hemispherical, not constricted at the base, $0.5-1 \mathrm{~mm}$ diam.; ostioles inconspicuous, black, 1 or 2 per verruca; spores 8 per ascus, irregularly uniseriate, ellipsoid-fusiform, smooth, 70-82 $\mu \mathrm{m}$ long, 32-42 $\mu \mathrm{m}$ wide.

Chemistry: thiophaninic acid, 2-O-methylperlatolic acid and lichexanthone (tr).

P. leucoxantha somewhat resembles P. xanthoplaca Müll. Arg. (q.v.) but is distinguished from that species by the fusiform spores, the lack of soredia and the presence of 2-O-methylperlatolic acid.

Also eXamined: QueEnSLAND: Glasshouse Mountains, c. $3 \mathrm{~km} \mathrm{~S}$ of Crookneck Mountain, on rhyolite outcrops, $100 \mathrm{~m}$, Hafellner 15802, July 1986 (GZU).

\section{Pertusaria lophocarpa Körber}

(Körber 1862: 34).

TyPE: Novae HollandiaE: s.loc. Hochstetter s.n.; holo WRSL.

Pertusaria glebosa Müll. Arg. (Müller 1882: 485). TYPE: VictoRIA: Grampians, Sullivan 14, - ; holo G.

Pertusaria diffracta Müll. Arg. (Müller 1893a: 43). TYPE: VICTORIA: Lorne, on sandstone rock by stream, F.R.M. Wilson 1055, May 1887; holo G; iso NSW L4436. 
Pertusaria arenacea Müll. Arg. (Müller 1895a: 29). TYPE: VICTORIA: Lorne, on sandstone rock by stream, F.R.M. Wilson 1056, May 1887; holo G; iso NSW L4477.

Pertusaria superba Zahlbr. (Zahlbruckner 1941: 332). Type: New Zealand: Otago, Mt Maungatua, J. Thomson ZA 287, May 1934; holo W.

Thallus off-white to pale fawn, thin and effuse to thick, then becoming cracked and areolate, surface smooth and dull, saxicolous; verrucae sparse and scattered to numerous and crowded, rarely confluent, conspicuous or almost immersed, flattened irregularly hemispherical often with concave tops, often constricted at the base, 1-2 (sometimes to 3 ) $\mathrm{mm}$ wide; ostioles conspicuous, black, 1 to 5 per verruca, sometimes sunken; spores 6 to 8 per ascus, uniseriate, ellipsoid, smooth, 45-75 $\mu \mathrm{m}$ long, 25-40 $\mu \mathrm{m}$ wide.

Chemistry: K-, KC-, C-, Pd-; 4,5-dichlorolichexanthone, 2'-O-methylperlatolic acid with or without planaic acid (tr) and anzaic acid (tr). New Zealand specimens may also contain confluentic acid as an additional major lichen acid, vide infra.

The type specimen of $P$. lophocarpa was collected by Hochstetter in Victoria (Filson 1986). Körber reported $P$. lophocarpa to contain four spores per ascus but the type specimen contains 4 to 8 spores per ascus.

$P$. lophocarpa occurs at all altitudes from sea level to $1460 \mathrm{~m}$ on coastal dolerite, basalt, sandstone and alpine Precambrian rock and is often conspicuous on exposed rocks. It occurs in Victoria, New South Wales, Tasmania and New Zealand and rarely in Queensland and South Australia.

P. lophocarpa superficially resembles the saxicolous New Zealand P. subverrucosa Nyl. but is distinguished from that taxon by the larger ostioles, the number of spores $(2$ per ascus in the New Zealand species) and the K- reaction ( $P$. subverrucosa reacts $\mathrm{K}+$ red due to the presence of norstictic acid).

Also examined (11 out of 47): QueEnsLAnd: Kroombit Tops National Park, $2 \mathrm{~km} S$ of Forestry Barracks [near Bundaberg], Rogers 7905, Sep 1985 (BRIU). New SoUTH WALEs: Lithgow, Wilson s.n., Sep 1897 (NSW L4578, L4582); Big Badja Hill, $47 \mathrm{~km} \mathrm{NE}$ of Cooma, Verdon 3473, Mar 1978 (CBG 8412495); Mt Kaputar Natl Park, West Kaputar Rocks, Merrotsy 454, Feb 1987 (BRIU). VICTORIA: Bogong High Plains, Basalt Hill, Filson 9760, Jan 1967 (MEL 1023586); Hanging Rock, c. $70 \mathrm{~km}$ NE of Melbourne, Hafellner 15749, July 1986 (GZU). TASMANIA: Mount Wellington, Gap Track, Bratt 1506 (HO 51049); Little Muselroe Bay, Moscal, Sep 1983 (AD 20493, HO 68795). South Australia: Mt Lofty Ranges, $4 \mathrm{~km} \mathrm{~W}$ of Carey Gully, Elix 2819, 2839, Dec 1976 (ANUC). New Zealand: Castle Rock, Port Hills, Christchurch, Elix 6980), Feb 1980 (ANUC).

\section{Pertusaria macra Müll. Arg.}

(Müller 1895a: 639).

TYPE: QUEENSLAND: Thursday Island, Knight 262, 1887; holo G.

Thallus thin, grey, minutely cracked and areolate, surface smooth and dull, saxicolous; verrucae conspicuous, numerous, scattered, flattened hemispherical, or sometimes immersed, 0.3-0.5 mm diam.; ostioles conspicuous, black, sunken, disclike, 1 per verruca, $0.2-0.4 \mathrm{~mm}$ diam.; spores 8 per ascus, irregularly biseriate, ellipsoid, smooth, 30-36 $\mu \mathrm{m}$ long, 17-20 $\mu \mathrm{m}$ wide.

Chemistry: stictic acid.

$P$. macra was reported from Queensland by Shirley (1896). It resembles $P$. concava (q.v.) and $P$. paratropa (q.v.) but is distinguished from both species by the presence of stictic acid, and from $P$. paratropa by the smaller spores.

P. macra is known only from the type specimen. 
17. Pertusaria meridionalis Mïll. Arg. [var.] $\alpha$ xanthostoma Müll. Arg. (Müller 1881: 516).

Lectotype (here selected): BraziL: Sao Paulo, Faxina, Puiggari 1221, June 1880; lecto G; residual syntypes $\mathrm{G}$.

Pertusaria amblygona Müll. Arg. (Müller 1895a: 638). TYPE: QueENSLAND: Toowoomba, Hartmann s.n., 1894; holo G.

Thallus off-white to pale yellowish grey, thin to thick, cracked or continuous, surface smooth and dull, corticolous; verrucae conspicuous, numerous, sometimes confluent, slightly flattened hemispherical, less conspicuous on rough substrates, $0.5-1(-1.5)$ mm wide; ostioles 1 per verruca, rarely 2, conspicuous, bright yellow, slightly convex, somewhat translucent, $0.3-0.4 \mathrm{~mm}$ diam., developing one or more yellow, mammiform projections, $0.05-0.15 \mathrm{~mm}$ diam.; spores 6 to 8 per ascus, irregularly uni- or biseriate, ellipsoid, smooth, 50-87 $\mu \mathrm{m}$ long, 22-37 $\mu \mathrm{m}$ wide.

Chemistry: thiophaninic acid, stictic acid and depside UN1, with or without norstictic acid (tr).

When Müller described Pertusaria meridionalis var. xanthostoma he referred to three specimens from South America; the specimen labelled '1221, Faxina, San Paulo, Brazil, Jun. 80, Puiggari' is the only specimen with a written reference to the publication, 'L.B. 338' [Lichenologische Beiträge XIV, number (338 Müller 1881)] and is therefore chosen as lectotype.

$P$. meridionalis var. xanthostoma occurs mainly in eastern Queensland and New South Wales, also in the Northern Territory and on Flinders Island in Bass Strait; it also occurs in Vanuatu, New Caledonia, Fiji and Brazil. It grows on mangroves, Leucopogon and other unspecified trees. It was also reported from Brisbane (Müller 1891) and from Goodna (Shirley 1891). The variety is distinguished from all other Australian Pertusaria species by the bright yellow ostioles which also distinguish it from the chemically similar North American $P$ xanthodes Müll. Arg., which has paler ostioles and two spores per ascus.

Also eXAMINED (11 out of 31): QueENSLAND: Brampton Island, Gilbert s.n., Aug 1972 (HO 50947); North Stradbroke Island near Myora Springs, Stevens 568, Feb 1975 (BRIU); Four Mile Creek, 6 km W of Cooktown, Elix 17420, July 1984 (ANUC). New South Wales: Park Beach, Coffs Harbour, Elix 3427 p.p., June 1977 (ANUC); 6 km N of Glen Martin, S of Dungog, Mayrhofer 8281, Aug 1988 (GZU). TASMANIA: Bass Strait, Flinders Island, Whinray s.n., Apr 1969 (MEL 1035537 p.p.). NorTHERN TERRITORY: Berry Springs [near Darwin], Beauglehole s.n., July 1965 (MEL 1028876 p.p.). Vanuatu [as New Hebrides]: Wilson s.n., 1895 (NSW L4654). New Caledonia: Nouméa, Wilson s.n., July $1891(\mathrm{H})$. Frj: Amba, Wilson s.n., Mar $1892(\mathrm{H})$.

\section{Pertusaria paeminosa A. Archer}

(A. Archer 1990: 395).

TyPE: NEW SOUTH WaLES: on exposed sandstone, Bairne Track, c. $30 \mathrm{~km} \mathrm{~N}$ of Sydney, A. Archer P 38, 14 Jan 1989; holo NSW; iso CBG.

Pertusaria sorediata Knight in Shirley (Shirley 1889: 141); nom. illeg., non Pertusaria sorediata (Fr.) Fr. 1846. TYPE: QuEENSLAND: Moreton Bay, J. Shirley 67, - ; holo WELT.

Thallus off-white to greyish white, moderately thick, margin well-defined and not zoned, areolate and cracked, surface smooth, sorediate, lacking isidia, saxicolous and corticolous; soralia white, conspicuous, becoming numerous and often confluent away from the margin, subspherical or flattened, sometimes becoming slightly stipitate in saxicolous specimens, $0.5-1.5 \mathrm{~mm}$ wide; apothecia rare, only in saxicolous specimens, disciform, 1-3 discs per soralia, discs dark brown, white pruinose, 0.2-0.5 mm diam., 
becoming exposed in stipitate soralia; asci clavate, 170-200 $\mu \mathrm{m}$ long, 50-60 $\mu \mathrm{m}$ wide; spores solitary, elongate ellipsoid, rarely lachrymoid, sometimes curved, 120-160 $\mu \mathrm{m}$ long, 35-50 $\mu \mathrm{m}$ wide, spore wall $1 \mu \mathrm{m}$ thick.

Chemistry: $\mathrm{K}$-ve or $\mathrm{K}+$ weak yellow, or rarely violet or red; $\mathrm{KC}$ - or + violet; $\mathrm{Pd}$-ve or $\mathrm{Pd}+$ yellow; lichexanthone and thamnolic acid \pm picrolichenic acid; rarely with additional norstictic acid in saxicolous and corticolous specimens or rarely with thamnolic acid replaced by hypothamnolic acid in saxicolous specimens.

P. paeminosa was originally reported to be sterile (Archer 1990) but a recent examination of additional specimens, from ANUC and MEL, found two fertile saxicolous specimens; no fertile corticolous specimens have so far been found. An amended description of $P$. paeminosa is given above.

$P$. paeminosa is a common, conspicuous white crustose lichen which may cover large areas on exposed sandstone and other rocks. It is often found with the saxicolous $P$. persulphurata Müll. Arg. (q.v.) The species appears to be restricted to the Great Divide and the coastal region in Eastern Australia. The corticolous form of $P$. paeminosa resembles $P$. novaezelandiae Szatala and P. erythrella Müll. Arg. (q.v.) but these taxa contain hypothamnolic and norstictic acids respectively in contrast to $P$. paeminosa which contains thamnolic acid. It grows on mangroves, Callitris, Ficus and other unspecified trees.

Also examined (11 out of 79): Saxicolous: QueEnsland: tip of Cape York Peninsula, Alice Filson s.n., July 1977 (MEL 1018913) [fertile]; Miami, South Nobby, Rogers 2424, Oct 1981 (BRIU); Mistake Mountains, near Doggs Falls, on basaltic rocks, Lumbsch 5699b, Sep 1987 (CBG, NSW, herb. LUMBSCH). New South WaLes: Sydney, South Head, Cheel s.n., May 1901 (NSW L4446); Currowan State Forest, $12 \mathrm{~km} \mathrm{~W}$ of Nelligen, Elix 3579, July 1977 (ANUC) [fertile]; Springwood, Sassafras Creek, $65 \mathrm{~km}$ W of Sydney, Archer P17, Aug 1988 (GZU, NSW). Australian CAPTTAL TerRitory: Gudgenby Gorge, $27 \mathrm{~km} \mathrm{~S}$ of Canberra, Lumbsch 5629b, Sep 1987 (CBG, herb. LUMBSCH, M, NSW). CorTiColous: QueEnsLAND: Noosa, Weybar Creek, Stevens 2375, Dec 1975 (BRIU); Cribb Island, Serpentine Creek, Stevens 1075, Sep 1975 (BRIU). NeW SouTH WALES: Springwood, Sassafras Creek, $65 \mathrm{~km}$ W of Sydney, Archer P8, July 1988 (NSW). Australian Caprtal TERRITORY: Gudgenby Gorge, $27 \mathrm{~km} \mathrm{~S}$ of Canberra, Lumbsch 5628f, Sep 1987 (herb. LUMBSCH).

\section{Pertusaria paratropa Müll. Arg.}

(Müller 1895a: 639).

TYPE: VICTORIA: Lorne, on sandstone rock by stream, F.R.M. Wilson 528, May 1887; holo G; iso NSW L4497, NSW L4498.

Thallus grey, areolate and cracked, saxicolous; verrucae numerous, scattered, disclike, almost immersed or less frequently raised and constricted at the base, $0.5-1 \mathrm{~mm}$ diam.; ostioles conspicuous, black, 1 per verruca, sunken in the verrucae; spores 8 per ascus, irregularly uniseriate to almost biseriate, ellipsoid, smooth, 37-55 $\mu \mathrm{m}$ long, 20 $30 \mu \mathrm{m}$ wide.

Chemistry: K-, KC-, C-, Pd-; no compounds detected by thin-layer chromatography.

P. paratropa occurs in Queensland and Victoria. It resembles P. macra (q.v.) but has larger spores and lacks stictic acid. The almost biseriate spore arrangement and the lack of lichen compounds (detectable by thin-layer chromatography) characterise this taxon.

Also eXAmINed: QueEnsLAnd: Cunninghams Gap National Park, Mt Cordeaux, on basaltic rock, Hafellner 15367, Sep 1986 (GZU). VICTORIA: Allansford Bridge, Allansford, c. $10 \mathrm{~km} \mathrm{E}$ of Warrnambool, Ewers s.n., Aug 1986 (herb. EWERS); Mt Eccles, Ewers s.n., Oct 1988 (herb. EWERS). 
20. Pertusaria persulphurata Müll. Arg.

(Müller 1891a: 391).

TYPE: Queensland: Brisbane, Bailey s.n.; holo G.

Pertusaria sulphurata Müll. Arg. (Müller 1893b: 125). Type: QueEnsland: Brisbane, Bailey s.n, 1891; holo G.

Thallus usually thin, rarely thick, pale to bright yellow, areolate and cracked, surface smooth and dull, with sparse to numerous scattered yellow soralia, $0.3-0.5 \mathrm{~mm}$ diam., saxicolous; verrucae and spores absent.

CHEMISTRY: K-, KC+ orange-red, $\mathrm{C}+$ orange, Pd-; thiophaninic acid, \pm lichexanthone \pm stictic acid. The chemistry of $P$. persulphurata (as $P$. sulphurata) was reported in detail by Elix et al. (1978).

$P$. persulphurata occurs in Queensland and New South Wales; it is a common and conspicuous species on exposed rock, often occuring with $P$. paeminosa (q.v.). $P$. fallax f. sulphurea was reported from Victoria (Wilson 1887) but Wilson's specimens with this name [from Upper Maffra (Wilson 476, NSW), Kilmore (NSW L4437) and Kew (NSW L4439)] are P. persulphurata.

P. persulphurata is distinguished from the yellow saxicolous P. xanthoplaca Müll. Arg. (q.v.) by the absence of verrucae and spores, and the presence of soralia.

Similar material, but with the soralia replaced by isidia, has also been seen from Queensland and other specimens, lacking both soralia and isidia, have also been seen and these are all tentatively included in P. persulphurata. In addition, specimens have been seen with yellow soralia on an off-white thallus; these appear a dull yellow in contrast to the bright yellow appearance of $P$. persulphurata which has yellow soralia on a yellow thallus. There is no chemical difference between these groups of specimens.

Also examined (6 out of 33): Queensland: Petford, c. $150 \mathrm{~km}$ W of Cairns, Hafellner 15091, 1979 (GZU); Brampton Island, Gilbert s.n., Aug 1972 (HO 50933); Lamington National Park, Castle Crag, Brownlie A91, May 1969 (MEL 1023504). New South WALES: Georges Creek, Macleay River, Boorman s.n., Jan 1907 (NSW L4438); Karuah River, W of Stroud, Filson 15331, May 1975 (MEL 1035840); $5 \mathrm{~km} \mathrm{~N}$ of Tenterfield, Laugher s.n., Aug 1975 (HO 50687).

\section{Pertusaria petrophyes Knight}

(Knight 1882: 47).

TYPE: New SOUTH WALES: [neighbourhood of Sydney, fide Filson (1986)], Knight 48, -; holo WELT; iso H-NYL 23608 n.v.

Thallus off-white to pale fawn, thin to effuse, surface rough and dull, saxicolous; verrucae numerous, crowded, sometimes confluent, flattened hemispherical with irregular outline, some constricted at the base, often inconspicuous on rough substrates, 1-2 mm wide; ostioles inconspicuous, black, 1 or 2 per verruca; spores 8 per ascus, uniseriate, ellipsoid, smooth, 60-85 $\mu \mathrm{m}$ long, 25-45 $\mu \mathrm{m}$ wide.

CHEMIsTRY: $\mathrm{K}-, \mathrm{KC}+$ weak orange $\mathrm{C}+$ weak orange, $\mathrm{Pd}$-; thiophaninic acid and lichexanthone.

$P$. petrophyes is superficially similar to $P$. lophocarpa but is distinguished from that taxon by the slightly larger spores and the different chemistry.

Also examined: Queensland: Cunninghams Gap National Park, on basaltic rock, Hafellner 15304, Sep 1986 (GZU). New Souty WaLes: Sydney, hills of Mona Vale, Bibby s.n., Feb 1942 (MEL 1023569); roadside between Sandy Hollow and Hollydeen, W of Muswellbrook, Mayrhofer 8257, Aug 1989 (GZU). 
22. Pertusaria plicatula Müll. Arg.

(Müller 1895a: 635).

TrPe: QueEnSLAND: s.loc., Knight 41 p.p., 1887; holo G.

Pertusaria straminea Müll. Arg. (Müller 1895a: 638). Type: QueEnsLAnd: Thursday Island, Hartmann s.n, 1887; holo G.

Thallus pale olive-green, thick, slightly wrinkled, cracked and areolate, surface smooth and dull, corticolous; verrucae conspicuous, numerous, occasionally confluent, slightly flattened hemispherical, $0.5-1.0 \mathrm{~mm}$ wide, becoming constricted at the base, the centre often depressed; ostioles inconspicuous, pale to dark brown, 1 to 5 per verruca, occasionally confluent; spores 2 per ascus, uniseriate, smooth, elongated ellipsoid, 100-137(-160) $\mu \mathrm{m}$ long, 30-45 $\mu \mathrm{m}$ wide.

ChEMISTRY: K-, KC-, C-, Pd-; 4,5-dichlorolichexanthone and stictic acid.

$P$. plicatula is characterised by the two-spored asci and the presence of 4,5-dichlorolichexanthone and stictic acid. It is distinguished from the morphologically and chemically similar $P$. communis var. neo-caledonica Nyl. (Nylander 1867) [lectotype (here selected): New Caledonia, Pancher s.n, 1862; H-NYL 22855] by the smooth spores (rough in var. neo-caledonica).

Also examined: QueEnsLand: Kuranda Range, NW of Cairns, Kalb 19915, Aug 1988 (herb. KALB). Vanuatu [as New Hebrides]: Aniwa, Wilson s.n., - 1891 (H).

\section{Pertusaria schizostomella Müll. Arg.}

(Müller 1895a: 637).

TYPe: New SOUth Wales: s.loc., C. Knight 31, - ; holo G.

Thallus pale yellowish green to pale greyish green, slightly or coarsely cracked and areolate, surface smooth or very slightly rough, dull, corticolous; verrucae scattered or crowded and becoming confluent, conspicuous, $0.5-1 \mathrm{~mm}$ diam., very slightly flattened hemispherical, not constricted at the base; ostioles conspicuous, pale, translucent, becoming dark in the centre, 1 per verruca; spores 2 per ascus, uniseriate, rough, ellipsoid, 80-120 $\mu \mathrm{m}$ long, 30-45 $\mu \mathrm{m}$ wide.

Chemistry: $\mathrm{K}-, \mathrm{KC}+$ orange, $\mathrm{C}+$ orange, $\mathrm{Pd}-$; thiophaninic and stictic acids.

$P$. schizostomella occurs in Queensland and New South Wales; it grows on mangroves and other unspecified trees. It is distinguished from the chemically and morphologically similar $P$. thiospoda by the rough spores, in contrast to the smooth spores in the latter taxon.

Also EXAmIned (6 out of 11): QueEnsLAnD: Turkey, Stevens 1241, Aug 1975 (BRIU); Indooroopilly, Hafellner 18578, 19284, Aug 1986 (GZU). NeW SourH WALEs: Newport, Wilson s.n., Oct 1881 (NSW L4499); Mangrove Creek, near Spencer, Mayrhofer 6585, Jan 1985 (GZU); Tweed Heads, Ewers s.n., July 1989 (herb. EWERS).

24. Pertusaria subrigida Müll. Arg. (Müller 1895a: 636).

TYPE: QueEnsland: Brisbane, Bailey 1570 (vide infra), 1891; holo G.

Thallus pale olive-green, coarsely cracked and areolate, surface irregularly tuberculate and dull, corticolous; verrucae conspicuous, scattered, approximately hemispherical, becoming constricted at the base, $1-1.5 \mathrm{~mm}$ diam.; ostioles inconspicuous, black, often sunken, 1 to 3 per verruca; spores 5-8 per ascus, irregularly uniseriate, fusiform, smooth, 70-110 $\mu \mathrm{m}$ long, $30-37 \mu \mathrm{m}$ wide. 
Chemistry: K-, KC-, C-, Pd-; no lichen compounds detected by thin-layer chromatography.

$P$. subrigida is characterised by the fusiform spores and the absence of lichen compounds detectable by thin-layer chromatography; it is distinguished from the morphologically similar P. leucostigma by the absence of 2-O-methylperlatolic acid. It occurs in eastern Queensland and New South Wales.

There is some confusion surrounding the number of the holotype specimen. The protologue refers to 'Bailey $\mathrm{n} .1870$ ' but the herbarium specimen is labelled 'Bailey 1570'. Shirley (1896) re-published Müller's descriptions (Müller 1895a) of 13 Queensland Pertusaria species in English and under P. subrigida referred to specimens from Brisbane and Toowoomba as 'Shirley no. 1870'! The herbarium specimen 'Bailey 1570 ' is also labelled 'Lecan. \& Lecid. N.18' [Lecanoreae et Lecideeae Australienses novae, species number 18 (Müller 1895a)] and is therefore the holotype. The difference between the number on the specimen and in the protologue is probably a printer's error as suggested by Filson (1986: 226).

Also examined: QueEnsLAnd: Mt Bullen, Bunya Mountains, Kalb 20249, 20271, Aug 1988 (herb. KALB). New SouTh Wales: Currowan State Forest, $2 \mathrm{~km}$ NW of Batemans Bay, Elix 21316, Dec 1986; Buladelah, Myall State Forest, Kalb 17938, Aug 1988 (herb. KALB); Barrington Tops National Park, Kalb 17988, 17998, Aug 1988 (herb. KALB).

\section{Pertusaria thiospoda Knight}

(Knight 1882: 47).

TYPE: New SOUTH WALES: [neighbourhood of Sydney, fide Filson (1986)], Knight 20, -; holo WELT.

Pertusaria leiotera Müll. Arg. (Müller 1884: 285). Type: QueEnsLand: Rockhampton, Thozet s.n., -; holo BRI.

Pertusaria minuta Knight in Shirley (Shirley 1889: 143). TYPE: QuEENSLAND: s.loc., F. Bailey s.n.; holo WELT.

Thallus pale yellowish white to pale yellow, thin, margin effuse, slightly cracked, surface smooth and dull, corticolous; verrucae inconspicuous, scattered to crowded, occasionally confluent, hemispherical, sometimes flattened, 0.5-1.0 mm diam., not constricted at the base; ostioles pale brown to black, 1 per verruca; spores 2 per ascus, uniseriate, ellipsoid, smooth, 80-110(-120) $\mu \mathrm{m}$ long, 30-40 $\mu \mathrm{m}$ wide.

CHEMISTRY: K-, KC+ yellow-orange, $\mathrm{C}+$ yellow-orange, $\mathrm{Pd}-$; thiophaninic acid, stictic acid with or without constictic acid (tr).

$P$. thiospoda is characterised by the pale yellow thallus, reacting $\mathrm{KC}+$ and $\mathrm{C}+$ orange, and the two-spored asci. It occurs in eastern Queensland and New South Wales, and rarely in the Northern Territory, Victoria and Tasmania, and also on Lord Howe Island, Norfolk Island and in Vanuatu. It grows on mangroves, Casuarina, Cyathodes and introduced trees such as Cotoneaster.

In appearance, chemistry and number of spores per ascus, P. thiospoda resembles P. subflavens Müll. Arg., which was first described from Socotra, Indian Ocean (Müller $1882 \mathrm{~b}$ ) and was later reported from Queensland (Shirley 1889). An examination of the holotype from Socotra [Socotra, Wadi-Kesche, Dr. Schweinfurth s.n., May 1881, G] showed it to contain thiophaninic and stictic acids but the spores (two per ascus) are larger than those of $P$. thiospoda, being 140-165 $\mu \mathrm{m}$ long and 55-60 $\mu \mathrm{m}$ wide, and are also slightly rough. No specimens corresponding to $P$. subflavens have been found among the Australian collections examined and the report of this taxon in Australia may be based on a misidentification of the more common $P$. thiospoda. 
$P$. thiospoda is distinguished from the chemically and morphologically similar P. schizostomella by the smooth spores, while the spores are rough in the latter taxon.

Also eXamined (8 out of 51): QueEnsLand: Burrum Heads, Stevens 1135, Aug 1975 (BRIU). New SOuth Wales: Laurieton, Stevens 2011, Aug 1977 (BRIU). VICtoRia: Kew, Wilson s.n., Dec 1884 (NSW L4493 p.p.). TASMANIA: Hogans Island, Bass Strait, Whinray s.n., Dec 1973 (MEL 1013008). NORTHERN TERRITORY: Bend 7, Tomkinson River, Arnhem Land, Grace s.n., May 1975 (MEL 1013779). LORD Howe IsLAND: Watts s.n., May 1904 (NSW L4551). NorfolK IsLAND: Maiden and Boorman s.n., Nov 1902 (NSW L4431). VanUATU [as New Hebrides]: s.loc., Wilson s.n., -1895 (NSW L4652).

26. Pertusaria trimera (Müll. Arg.) A. Archer, comb. nov.

BAsionym: Pertusaria pustulata (Ach.) Duby var. trimera Müll. Arg. (Müller 1893a: 42).

LECTOTYPE (here selected): Victoria, 'at Kew, at Oakleigh \& at Camperdown' [although there are three localities on the label, there is only one specimen], F.R.M. Wilson 473; lecto G; residual syntypes: F.R.M. Wilson 474 p.p., F.R.M. Wilson 481, F.R.M. Wilson 483; G.

Pertusaria melaleuca (Sm. \& Sowerby) Duby var. trispora Müll. Arg. (Müller 1893a: 42). SYNTYPES: Victoria, 'at Kew, at Youyangs and at Doncaster' [although there are three localities on the label, there is only one specimen], F.R.M. Wilson 474 p.p., 1892; Kew, F.R.M. Wilson 482, 1892; G, NSW.

Thallus pale greyish green to pale yellowish green, thin, slightly cracked, surface smooth and dull, corticolous; verrucae conspicuous, scattered, rarely confluent, very flattened hemipherical 0.4-0.8 mm diam.; ostioles conspicuous, black, 1 to 4 per verrucae; spores 3 to 4 per ascus, uniseriate, elongate-ellipsoid, smooth, $70-110 \mu \mathrm{m}$ long, 30-40 $\mu \mathrm{m}$ wide.

CHEMISTRY: $\mathrm{K}$ - or $\mathrm{K}+$ red, $\mathrm{KC}+$ orange, $\mathrm{C}+$ orange, $\mathrm{Pd}$ - or $\mathrm{Pd}+$ yellow; thiophaninic acid and 2-O-methylperlatolic acid and/or norstictic acid.

Variety trimera and variety trispora are morphologically similar, with yellow thalli due to the presence of thiophaninic acid, and similar verrucae and ostioles, each with three to four smooth, ellipsoid spores of similar size in the ascus. Jean Müller even included parts of the same specimen, Wilson 474, as syntypes for both varieties (Müller loc. cit.). Both taxa were published in the same article but var. trimera was described in more detail than var. trispora and var. trimera is typified by a better range of specimens. P. 'melaleuca' var. trispora is therefore considered to be a synonym of $P$. pustulata var. trimera.

P. pustulata (Ach.) Duby is a two-spored, temperate species of the Northern Hemisphere (Dibben 1980: 105) containing an unknown xanthone and stictic acid and is therefore unrelated to $P$. pustulata var. trimera. This variety is accordingly raised to species level, under the name $P$. trimera following Recommendation $61 \mathrm{~A} 3$ of the International Code of Botanical Nomenclature 1988.

P. trimera occurs in Western Australia, South Australia, Victoria and Tasmania; it is characterised by the yellow thallus, small verrucae with conspicuous black ostioles and 4 spores per ascus.

When J. Müller described P. pustulata var. trimera he cited four specimens, Wilson 473 , 474 p.p., 481 and 483 ; the specimen Wilson 473 is the only specimen labelled with a written reference to the publication viz. 'L. Wilson n. 61' [Lichenes Wilsoniani, taxon number 61 (Müller, 1893)] and is therefore chosen as lectotype.

Also EXAMINED (11 out of 25): VICTORIA: Gippsland, Campbell s.n., Dec 1885 (NSW L4489); near Dimboola, Reader s.n., June 1896 (NSW L4544); Capi Plain, Wyperfeld National Park, Filson, Aug 
1978 (MEL 1023060); Mt Arapiles, Mayrhofer 6638, Aug 1981 (GZU). Tasmania: Campbell Town near Elizabeth River, Bratt 4082, June 1967 (HO 51157); near Broadmarsh Post Office, c. $30 \mathrm{~km}$ NNE of Hobart, Bratt 68/541, July 1968 (HO 51140). SOUTH Australia: Talbots Reserve, $4.5 \mathrm{~km}$ W of Tepko, Mt Lofty Ranges, Elix 9414, Oct 1981 (ANUC); Penola Forest Reserve, Munir 54788, Nov 1981 (AD 20147 p.p.). Western Australia: $40 \mathrm{~km} \mathrm{E}$ of Ravensthorpe on Highway 1, Richardson 291, Apr 1980 (PERTH 000946); Gairdner River, at South Coast Highway, Richardson 250, Apr 1980 (PERTH 000946); 10 km S of Kulin, Hnatiuk 770537, July 1977 (PERTH 000621).

27. Pertusaria undulata Müll. Arg.

(Müller 1893b: 126).

Type: QueEnsland: s.loc., Hartmann s.n.; holo G; iso BM n.v.

Thallus pale olive green, coarsely cracked and areolate, surface slightly rough and dull, corticolous; verrucae inconspicuous, flattened hemispherical or irregular in outline, becoming slightly constricted at the base, rarely confluent, $0.5-1.5 \mathrm{~mm}$ diam., sometimes concave on top; ostioles inconspicuous, pale, 1 or 2 per verruca; spores 8 per ascus, irregularly biseriate, elongate-ellipsoid to fusiform, smooth, $67-85 \mu \mathrm{m}$ long, $27-35 \mu \mathrm{m}$ wide.

Chemistry: K+ red, KC-, C-, Pd+ yellow; 4,5-dichlorolichexanthone and norstictic acid.

$P$. undulata was also reported from Toowoomba (Shirley 1893). The taxon is characterised by the eight fusiform spores and the presence of norstictic acid and is distinguished from the chemically similar $P$. hartmannii (both react $\mathrm{K}+$ red) by the number of spores (two per ascus in $P$. hartmannii). Müller in the protologue related $P$. undulata to $P$. gibberosa but noted differences in the ostioles and the size of spores. These two taxa are distinguished by the arrangement of the spores within the ascus and by the $\mathrm{K}+$ red reaction of $P$. undulata, which is negative with $P$. gibberosa.

Also eXAmined: QueENSLAND: Weyba River Estuary, Noosaville, Elix 19308, Sep 1985 (ANUC). New SOUtH WaLEs: Minyon Falls, 25 km NE of Lismore, Verdon 3935, Oct 1982 (CBG 7809416).

\section{Pertusaria velata (Turn.) $N y l$.}

(Nylander 1861: 179).

Parmelia velata Turn. (Turner 1808: 143). TYPE: ENGLAND: Sussex, on ash trees, Borrer s.n., 1805; holo BM n.v.

Pertusaria rhodotropa Müll. Arg. (Müller 1895a: 637). Lectotype (here selected): QuEENSLAND: s.loc., Knight 308 p.p.; lecto G; residual syntypes: Knight 30, 32 p.p., 307, 309, all in G.

Thallus greyish white to off-white, thick, slightly cracked and areolate, surface smooth to slighly wrinkled, dull; esorediate, corticolous; verrucae numerous, crowded, immature verrucae irregularly hemispherical or subspherical, constricted at the base, 0.5-1.0 mm wide, mature verrucae becoming flattened and exposing pale to dark reddish brown discs, $0.5-0.8 \mathrm{~mm}$ diam., slightly or densely white pruinose; spores 1 per ascus, uncommon, smooth, ellipsoid, thin-walled, 110-140(-175) $\mu \mathrm{m}$ long, 30-45 $\mu \mathrm{m}$ wide.

CHEMISTRY: K-, KC+ orange, $\mathrm{C}+$ orange, $\mathrm{Pd}-$; lecanoric acid.

$P$. velata is a widespread species with a pantropical and temperate distribution; it has been reported from Europe, North and South America [including Brazil (Vainio 1890)], China, Japan, Hawaii, the Philippines and the Mariana Islands (Dibben 1980: 78). It has also been reported from New Caledonia (Nylander 1867) and, in Australia, from Queensland (Shirley 1889) and New South Wales (Elix \& Streimann 1982). P. velata is 
found in Australia at or near sea-level in eastern Queensland and New South Wales; it grows predominantly on mangroves and also on other unspecified trees.

Müller (loc. cit.) compared $P$. rhodotropa to the Central American P. subvaginata Nyl. (Nylander 1866), which was reported from Brisbane (Müller 1891a), Bundaberg (Shirley 1891) and Toowoomba (Müller 1892). An examination of the holotype of P. subvaginata Nova Granata, Lindig s.n.; H-NYL 23508] showed it to contain lichexanthone, which distinguishes this species from $P$. rhodotropa. P. subvaginata has not been found among the recent Pertusaria collected in Queensland or New South Wales.

When Müller described P. rhodotropa he cited five specimens, Knight 30, 32 p.p., 307, 308 p.p., and 309 . The specimen labelled 'Knight 308 p.p.' is the only specimen with a reference to the publication viz 'Lecan. \& Lecid. no. 13' [Lecanoreae et Lecideeae Australienses novae, species number 13 (Müller 1895a)] and this specimen is therefore selected as lectotype.

A chemically and morphologically similar taxon, so far unnamed, occurs in Western Australia but this is distinguished from $P$. velata by its eight-spored asci.

$P$. velata is characterised by the single-spored asci and the $\mathrm{KC}+$ orange reaction, due to the presence of lecanoric acid.

ALSO EXAMINED (12 out of 50): QUEENSLAND: North Stradbroke Island, Rogers 242, May 1973 (BRIU); Fraser Island, Stevens 713, May 1975 (BRIU); Turkey, Stevens 1236, Aug 1975 (BRIU); $25 \mathrm{~km} \mathrm{~S}$ of Lockhart, Hill s.n., Sep 1976 (MEL 1035496). New South W WLes: Park Beach, Coffs Harbour Elix 3428, June 1977 (ANUC); Jervis Bay, Verdon 3092, Sep 1977 (CBG 7802797 p.p.); Diamond Creek, $22 \mathrm{~km} \mathrm{SW}$ of Moruya, Verdon 5082, Nov 1981 (CBG, H); Cowan Creek, c. $30 \mathrm{~km} \mathrm{~N}$ of Sydney, Archer P86, P92, Jan 1990 (NSW). Vandatau [as New Hebrides]: on coconut palm, Wilson 1834, - 1895 (NSW). U.S.A.: Iowa: Fayette, Fink s.n., Aug 1894 (NSW). MarYLAND: Baltimore County, Pitt 54b, July 1910 (NSW). LouISIANA: Washington Parish, Frickes Bluff, Tucker 25959, Feb 1984 (BRIU).

29. Pertusaria woollsiana Müll. Arg.

(Müller 1882a: 485).

TYPe: New SOUTH WaLes: Parramatta, Woolls s.n., 1879; holo G; iso MEL 7288.

Thallus off-white to pale greyish green, slightly cracked and areolate, surface smooth and dull, corticolous; verrucae conspicuous, numerous, scattered, flattened hemispherical, not constricted at the base, $0.5-1 \mathrm{~mm}$ diam.; ostioles inconspicuous, dark brown, 2 to 7 per verruca; spores 6 to 8 per ascus, uniseriate, ellipsoid, smooth, 53$60 \mu \mathrm{m}$ long, 24-30 $\mu \mathrm{m}$ wide.

Chemistry: K-, KC-, C-, Pd-; 4,5-dichlorolichexanthone and 2-o-methylperlatolic acid.

$P$. woollsiana is known only from the type specimens. J. Müller (loc. cit.) reported $P$. woollsiana to contain four spores per ascus but the type material contains at least six mature spores per ascus with some asci containing eight immature spores. The material examined resembles $P$. gibberosa (q.v.) and differs only in the chemistry.

\section{Pertusaria xanthoplaca Müll. Arg.}

(Müller 1882a: 485).

TYPE: QUEENSLAND: Toowoomba, Hartmann 32, 1881; holo G; iso MEL 7286.

Thallus bright yellow, thin, minutely cracked and areolate, surface smooth and dull, rarely isidiate, esorediate, saxicolous; verrucae scattered or numerous, rarely confluent, slightly flattened hemispherical, becoming constricted at the base, $0.5-1 \mathrm{~mm}$ diam.; ostioles inconspicuous, pale or becoming dark, 1 per verruca; spores 8 per 
ascus, irregularly uniseriate, ellipsoid, rarely becoming subfusiform, smooth, 50-75 $\mu \mathrm{m}$ long, 25-37 $\mu \mathrm{m}$ wide.

Chemistry: K-, $\mathrm{KC}+$ orange, $\mathrm{C}+$ orange, $\mathrm{Pd}-$; thiophaninic acid, lichexanthone and rarely lacking stictic acid.

ALSO EXAMINed (7 out of 16): QueENSLAND: Brampton Island, Gilbert s.n., Aug 1974 (HO 50946); Cooktown Road, $3 \mathrm{~km}$ NW of Mt Molloy, Elix 17184, July 1984 (ANUC); Paluma Valley Reservoir, Hidden Valley Track, $34 \mathrm{~km}$ SSW of Ingham, Elix 20299, June 1986 (ANUC); Mt Stuart, $10 \mathrm{~km} \mathrm{SSW}$ of Townsville, Elix 21230, July 1986 (ANUC); Glasshouse Mtns, $3 \mathrm{~km}$ S of Crookwell, Hafellner 15813, July 1986 (GZU). New South WaLEs: Port Macquarie, Elix 1067, Aug 1975 (ANUC); Broken Head, 8 km S of Byron Bay, Elix 21253, Aug 1986 (ANUC).

P. xanthoplaca occurs in eastern Queensland and New South Wales on rhyolite, granite, porphyry and volcanic rock, from sea level to $880 \mathrm{~m}$. It is chemically similar to $P$. persulphurata but is differentiated from that species by the absence of soralia and the frequent presence of fertile verrucae.

\section{Acknowledgements}

The author is grateful to the colleagues and herbaria referred to above for the loan of specimens, and in particular to Dr J.A. Elix (Canberra) for the gift of authentic lichen acids and assistance with some chemical analyses, and to the National Herbarium of New South Wales for arranging loans of type specimens and for permission to use the facilities of the Herbarium.

\section{References}

Archer, A.W. (1978) 3-Methyl-2-benzothiazolone hydrazone hydrochloride as a spray reagent for phenolic lichen compounds. J. Chromatogr. 152: 290-292.

Archer, A.W. (1987) Two new lirhens: Cladonia squamosula var. subsquamosula and C. sulcata var. striata with notes on chemotaxonomy within the species. Muelleria 6(5): 383-388.

Archer, A.W. (1990) A new species in the lichen genus Pertusaria from the Southern Hemisphere: Pertusaria paeminosa. Nova Hedwigia 50: 395-399.

Culberson, C.F. (1972) Improved conditions and new data for the identification of lichen compounds by a standardised thin-layer chromatographic method. J. Chromatogr. 72: 113-125.

Dibben, M.J. (1980) The chemosystematics of the lichen genus Pertusaria in North America north of Mexico. Milwaukee Public Museum Publications in Biology and Geology, Number 5. (Milwaukee).

Elix, J.A., Musidlak, H.W., Sala, T. \& Sargent, M.V. (1978) Structure and synthesis of some lichen xanthones. Austral. J. Chem. 31: 145-155.

Elix, J.A. \& Streimann, H. (1982) New lichen records for Australia. J. Hattori Bot. Lab. 51: 69-97.

Filson, R.B. (1986) Index to the type specimens of Australian lichens, 1800-1984. Australian Flora and Fauna Series Number 4. (Australian Government Publishing Services: Canberra).

Galloway, D. J. (1985) Flora of New Zealand lichens. (Government Printer: Wellington).

Hanko, B. (1983) Die Chemotypen der Flechtengattung Pertusaria in Europa. Bibliotheca Lichenologica Band 19. (J. Cramer: Vaduz).

Knight, C. (1882) Contributions to the lichenographia of New South Wales. Trans. Linn. Soc. London, Bot. 2: 37-51.

Körber, G.W. (1862) Reliquiae Hochstetterianae. Abh. Schles. Ges. Vaterl. Cult., Abth. Naturwiss. 2: $30-34$.

Magnusson, A. H. (1955) A catalogue of the Hawaiian lichens. Arkiv för Botanik, ser. 2, 3: $223-$ 402.

Müller, J. (1881) Lichenologische Beiträge XIV. Flora 64: 513-527.

Müller, J. (1882a) Lichenologische Beiträge XVI. Flora 65: 485-486. 
Müller, J. (1882b) Diagnoses lichenum socotrensium novorum. Proc. Roy. Soc. Edinburgh 11: 461.

Müller, J. (1883) Lichenologische Beiträge XVII. Flora 66: 75-80.

Müller, J. (1884) Lichenologische Beiträge XIX. Flora 67: 349-354; 460-468.

Müller, J. (1891a) Lichenes Brisbanenses. Nuovo Giorn. Bot. Ital. 23: 385-404.

Müller, J. (1891b) Primitiae Florae Costaricensis. Lichens. Bull. Soc. Roy. Bot. Belgique. 30(1): 4997.

Müller, J. (1892) Lichenes exotici Herbari Vindobonensis. Ann. K. K. Naturhist. Hofmus. 7: 302305.

Müller, J. (1893a) Lichenes Wilsoniani. Bull. Herb. Boissier 1: 33-65.

Müller, J. (1893b) Lichenes Exotici II. Hedwigia 32: 120-136.

Müller, J. (1895a) Lecanoreae et Lecideeae Australienses novae. Bull. Herb. Boissier 3: 632-642.

Müller, J. (1895b) Lichenes Exotici III. Hedwigia 34: 27-38.

Nylander, W. (1859) Lichenes Exotici. Ann. Sci. Nat. Bot. (4)11: 241.

Nylander, W. (1861) Lichenes Scandinaviae (Helsinki).

Nylander, W. (1866) Collectio Lichenum ex Insula Cuba. Flora 49: 289-295.

Nylander, W. (1867) Synopsis Lichenum Novae Caledoniae. Bull. Soc. Linn. Normandie ser.2, 2: 508-521.

Nylander, W. (1890) Lichenes Japoniae (Paris).

Shirley, J.F. (1889) The Lichen Flora of Queensland. Proc. Roy. Soc. Queensland 6: 138-145.

Shirley, J.F. (1891) in Bailey, F.M., Contributions to the Queensland Flora, Botany Bulletin III. Queensland Dept. Agric. Bull. 9: 26-27.

Shirley, J.F. (1893) in Bailey, F.M., Contributions to the Queensland Flora, Botany Bulletin VIII. Queensland Dept. Agric. Bull. (s.n.): 98-99.

Shirley, F.J. (1896) in Bailey, F.M. Contributions to the Queensland Flora, Botany Bulletin XIII. Queensland Dept. Agric. Bull. (s.n.): 20-22.

Stirton, J. (1876) New and rare lichens. Trans. Glasg. Soc. Fld. Nats. 4: 93.

Turner, D. (1808) Description of eight new British lichens. Trans. Linn. Soc. London 9: 135-150.

Vainio, E.A. (1890) Etude sur la classification naturelle et la morphologie des lichens du Brésil. Pars prima. Acta Soc. Fauna Flora Fenn. 7(1): 1-247.

Wilson, F.R.M. (1887) Notes on a few Victorian lichens. Victorian Naturalist 4: 83-87.

Zahlbruckner, A. (1928) Catalogus lichenum universalis vol. 5 (Leipzig).

Zahlbruckner, A. (1941) Lichenes Novae Zelandiae a cl. H. H. Allan eiusque collaboratoribus lecti. Kaiserl. Akad. Wiss. Wien math.-naturwiss. Kl., Denkschr. 104: 249-380.

\section{Index of taxa}

Names in Roman type are accepted names; names in italics are synonyms and the name in bold type is a new combination.

Parmelia velata

Pertusaria aberrans

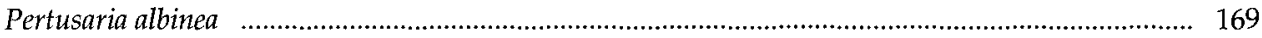

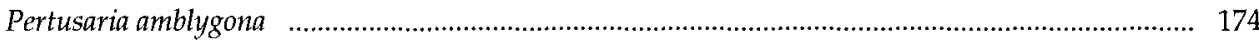

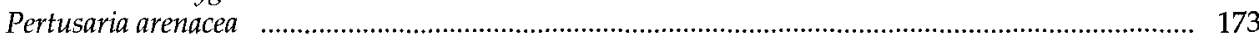

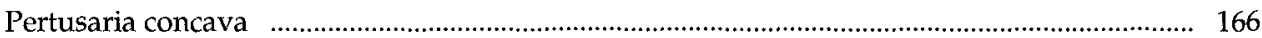

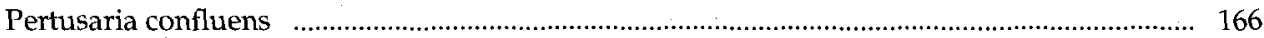

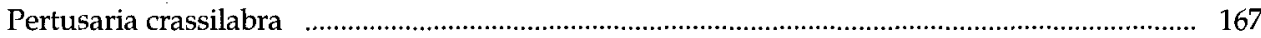

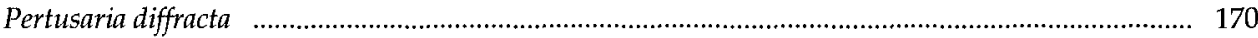

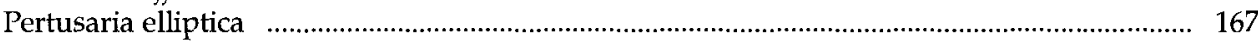

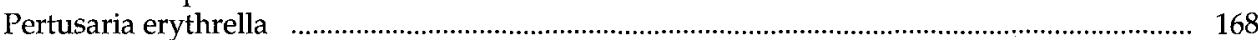

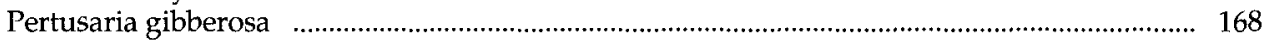

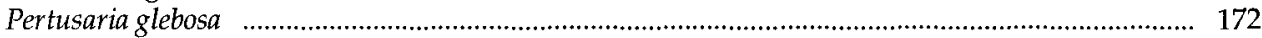

Pertusaria graphidioides .............................................................................................. 168

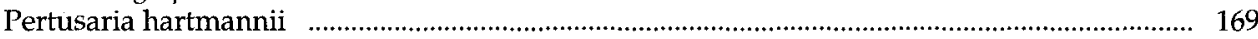

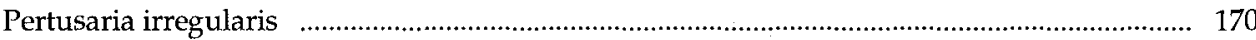




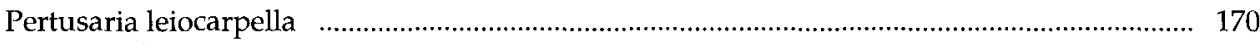

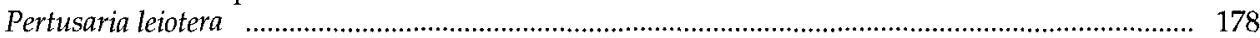

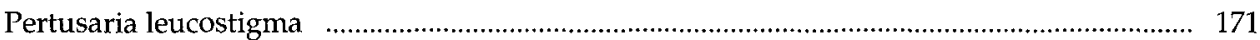

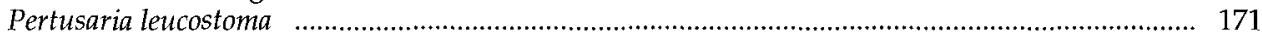

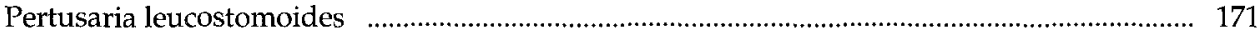

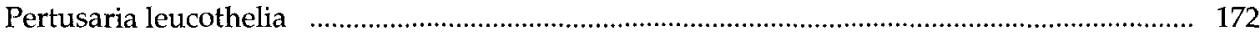

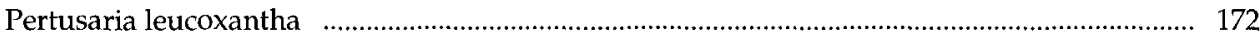

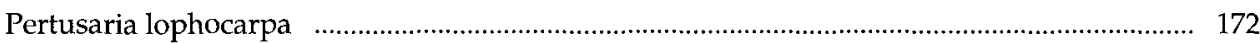

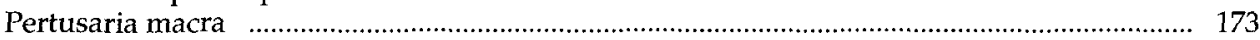

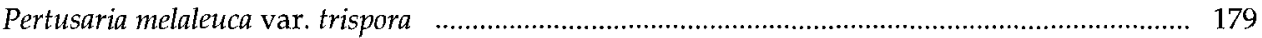

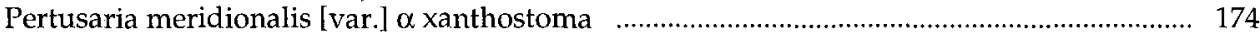

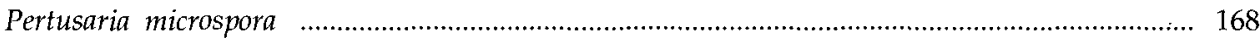

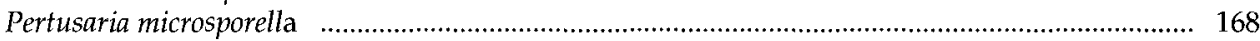

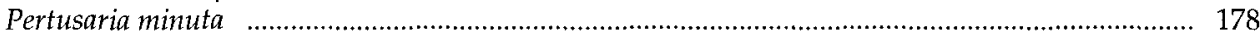

Pertusaria moffatiana .......................................................................................................... 168

Pertusaria muelleriana ...................................................................................................... 169

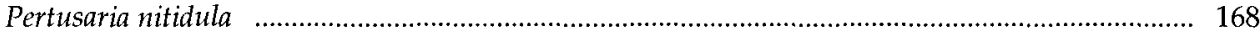

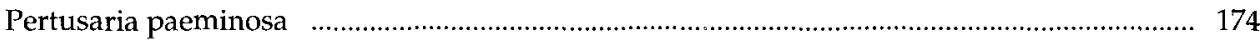

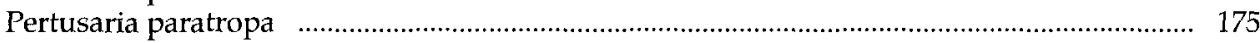

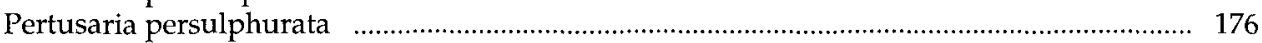

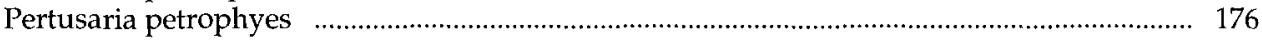

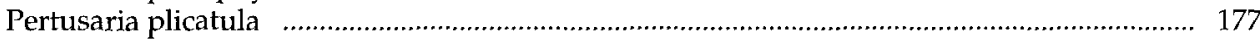

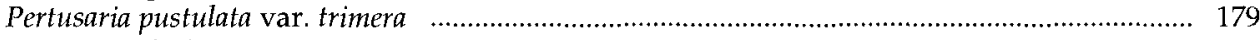

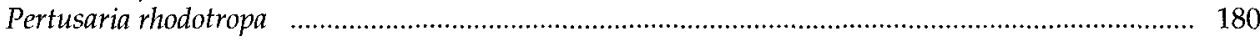

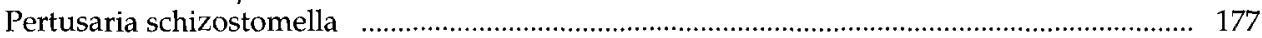

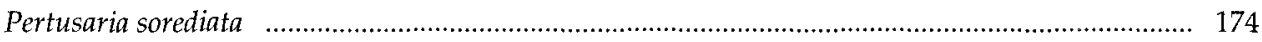

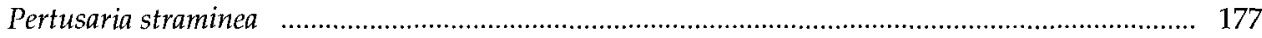

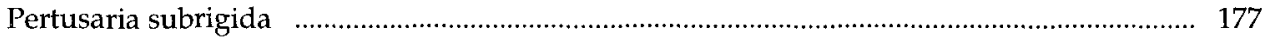

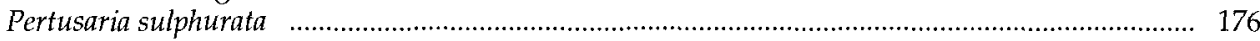

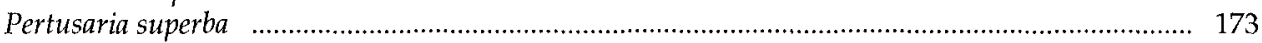

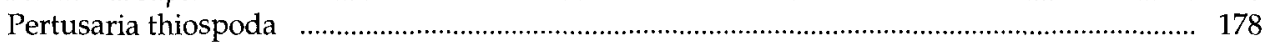

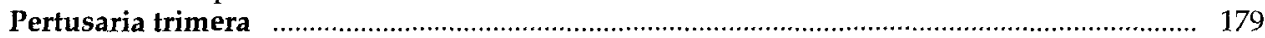

Pertusaria trypetheliiformis var. hartmannii ………........................................................... 169

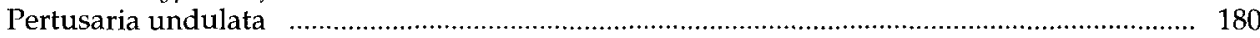

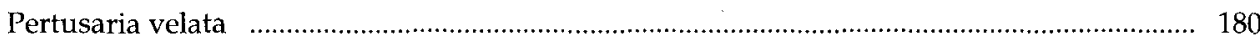

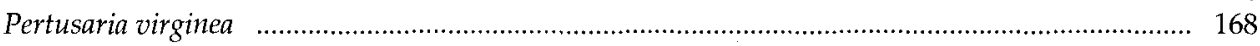

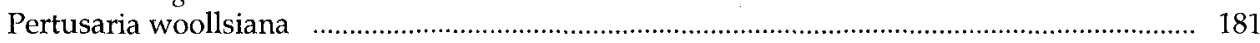

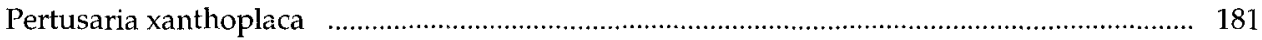

Manuscript received 7 May 1990

Manuscript accepted 2 November 1990 